\title{
当院における卵巣成熟奇形腫手術症例の検討
}

独立行政法人国立病院機構東京医療センター産婦人科

山下＼cjkstart博、吉津照見、三辻礼美、野上侑哉、辻 浩介、植木有紗、 大野暁子、三上佳子、山本阿紀子、高橋 純

\section{Clinical features of mature ovarian teratoma cases: A single institutional experience}

Hiroshi Yamashita, Terumi Yoshizu, Hiromi Mitsuji, Yuya Nogami, Kosuke Tsuji, Arisa Ueki, Akiko Ohno, Yoshiko Mikami, Akiko Yamamoto, Jun Takahashi

Department of Obstetrics and Gynecology, National Hospital Organization Tokyo Medical Center

\begin{abstract}
Objective: Clinical features of mature ovarian teratoma cases were investigated.

Methods: A total of 185 patients with mature ovarian teratoma surgically treated at our hospital between 2009 and 2013 were included in this study. Clinical data were obtained from patients' medical records. Clinical variables were analyzed by student's t-tests. Pearson correlation analyses were performed to analyze the correlation between tumor size and tumor markers (squamous cell carcinoma antigen (SCC) and CA19-9).

Results: Pearson correlation coefficients between tumor size and SCC, and tumor size and CA19-9 were 0.270 and 0.413, respectively. Age, tumor size, and squamous cell carcinoma antigens in the laparotomy group were significantly higher than those in the laparoscopy group. In the salpingo-oophorectomy group, only age was significantly higher than that in the cystectomy group.

Conclusion: Age, tumor size, and squamous cell carcinoma antigens may affect the decision to perform laparotomy in mature teratoma patients. Since tumor markers are related to tumor size, we should consider the possibility of the effect of tumor size in cases of ovarian mature teratomas with abnormal tumor markers.
\end{abstract}

Key words: ovarian mature teratoma, tumor marker, laparoscopic surgery

\section{諸言}

卵巣の成熟奇形腫は全卵巣腫瘍の10-40\%を占 めると言われている良性卵巣腫瘍であり ${ }^{1,2)}$ 、腹腔 鏡手術症例としても頻繁に経験する。奇形腫の手 術療法においては、悪性の可能性の有無は術式決 定のための重要な要因であり、通常腫瘍マーカー 検査とMRIなどの画像検査を用いて総合的な評価 を行う。腫瘍マーカーとしてはしばしばCA19-9 やSCCが異常值を示すが、術式決定にどの程度こ れらの異常を考慮すべきかについての指針は無 く、このような症例の術式決定にはしばしば苦慮 する。当院においては術式の選択は諸検査や患者
の希望に基づいて総合的に主治医が判断してお り、術式決定に関するアルゴリズムは存在してい ない。今回我々は、当院における卵巣成熟奇形腫 に対して手術を行った症例について臨床的特性に ついて後方視的検討を行ったので報告する。

\section{方 法}

2009年 1 月より2013年12月までに当院にて手術 を行い、病理学的に成熟奇形腫であることが確認 された185例を対象とした。なお、術前の画像検 査で悪性卵巣腫瘍が疑われた症例は除外した。当 院倫理委員会の承認のもと、診療記録に基づき対 象症例集団の基本的特徵を検討した。その上で腫 
瘍マーカーと腫瘍の大きさとの相関について検討 を行った。また、術式ごとの患者特性を比較する ために術式間の年齢、腫痬の大きさ、腫瘍マーカ 一（CA19-9およびSCC)、および茎捻転の有無な どについて比較を行った。さらに、2016年 5 月に おける再発の有無についても検討を行った。

腫瘍の大きさについては、他の報告と比較する ために患者背景については腫瘍の最大径を用いた が、腫瘍マーカーとの相関を検討する際には成熟 奇形腫のほとんどの症例が囊胞性であり、体積よ りも表面積 $(\mathrm{S})$ に対する相関性を検証することが 合理的であると考元、MRIおよびCT画像より腫 瘍の長径 $(\mathrm{D})$ を計測し、腫瘍表面積 $(\mathrm{S})$ は、腫瘍 長径 (D) を用いて $\mathrm{S}\left(\mathrm{cm}^{2}\right)=4 \times 3 \times \mathrm{D}(\mathrm{cm}) / 2$ で近 似し、腫揚が複数個ある場合にはそれらの和を用 いた。

術式別の年齢、腫瘍表面積、および腫瘍マーカ 一の平均值の差の検定には土検定を用いた。

腫瘍マーカーと腫瘍表面積との相関の検討につい てはPearsonの積率相関を用いて解析した。

\section{結 果}

成熟奇形腫の患者背景について表 1 に示す。年 齢の中央值は33歳 (16歳 85歳)、腫瘍最大径の

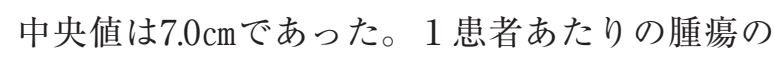
数は 1 個が 149 例 $(80.5 \%)$ と最多であり、ついで 2 個が27例 (14.6\%)、3 個が 9 例 (4.9\%) であっ た。左右差については右、左、両側性がそれぞれ 80例、69例、および36例であった。また、手術症 例のうち茎捻転が認められたものは20例 (10.8\%) であった。腫瘍マーカーについては、CA19-9が 測定されていた144例の中央值（範囲）が27.35U/ $\mathrm{ml}$ (0.6-4245)、SCCが測定されていた134例の中 央值（範囲）が1.0ng/ml（0.5-9.7）であった。 CA19-9 が上限を超えていたのは59例（41.0\%） でありSCCについては23例（17.2\%）であった。

これらの患者背景をふまえ、腫瘍表面積と腫瘍 マーカー（SCCおよびCA19-9）との相関性につ いて検討をおこなった。Pearsonの積率相関係数 およびその検定によれば、腫瘍表面積とSCCの間 の相関係数は $0.270(\mathrm{p}<0.001)$ と弱い相関関係が 認められ、腫瘍表面積とCA19-9の間では相関係 数は $0.413(\mathrm{p}<0.001)$ と中等度の相関が認められ た（図 1)。今回検討を行った185例とは別に調査 期間中に 1 例のみ術前に長径 $12.5 \mathrm{~cm}$ の成熟奇形腫 と考えられていたが、術後の病理検査にて扁平上 皮癌への悪性転化が判明した症例を経験した。悪
表 1 患者背景

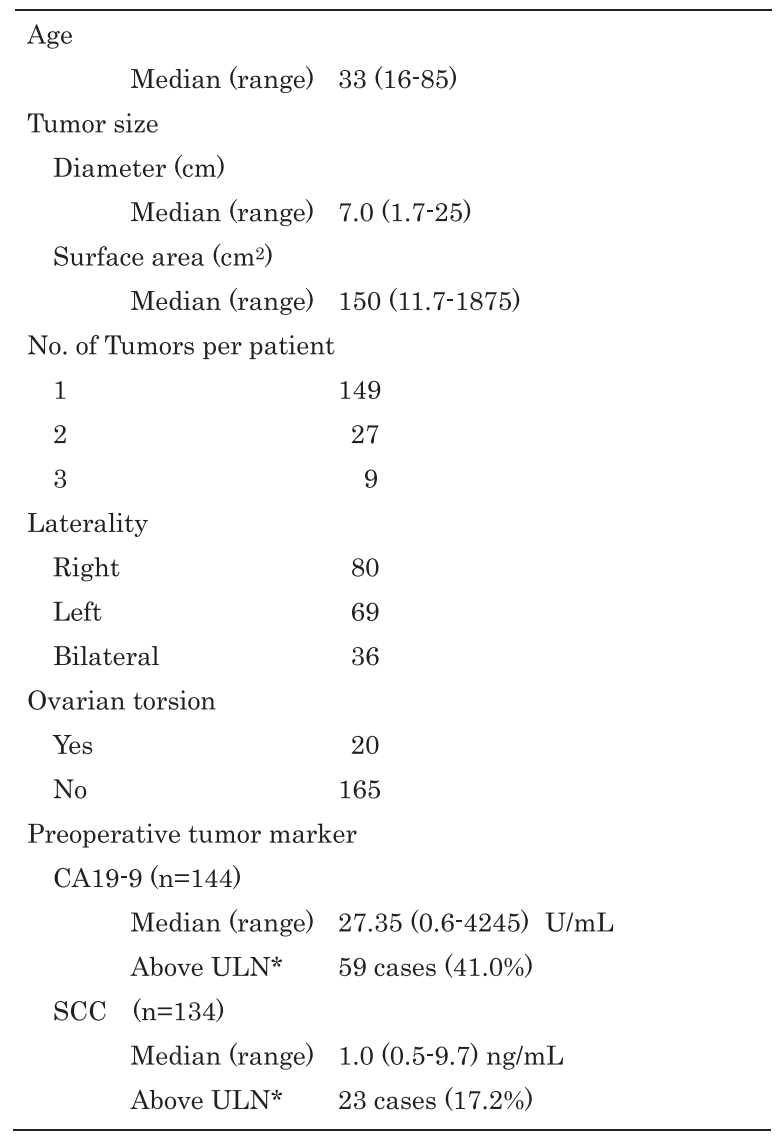

*ULN: upper limit of normal

性転化症例のSCCおよびCA19-9 と腫瘍表面積の 関係を図 1 に星印でプロットしたところ、良性例 に対してSCCが著しく高かった。

次に術式の内訳を表 2 に示す。当院においては 成熟奇形腫に対しては腹腔鏡手術が145例 (78.4\%) に施行されており、開腹手術は40例（21.6\%）に 施行されていた。腹腔鏡手術症例においては付属 器摘出が施行されたのは145例中45例 (31.0\%) で あったが、開腹手術症例においては40例中 24 例 (60.0\%) と腹腔鏡手術に比べて高い割合であった。 緊急手術症例である茎捻転の 20 例とその他の待機 的手術の 165 例を比較してみると、茎捻転症例に おいて最も多かった術式は腹腔鏡下付属器摘出術 (45\%) であったのに対し、待機的手術症例にお いて最も多かった術式は腹腔鏡下震腫摘出術（59 \%) であり、茎捻転症例と待機的手術症例では術 式の分布が異なっていた（図2)。そこで待機的 手術の165例について術式間の年齢、腫瘍表面積、 および腫瘍マーカーの平均值の差について検討を 行った (表 3 )。開腹手術と腹腔鏡手術の比較に おいては年齢、腫瘍表面積、およびSCCの平均值 が開腹手術において有意に高かった。また、付属 

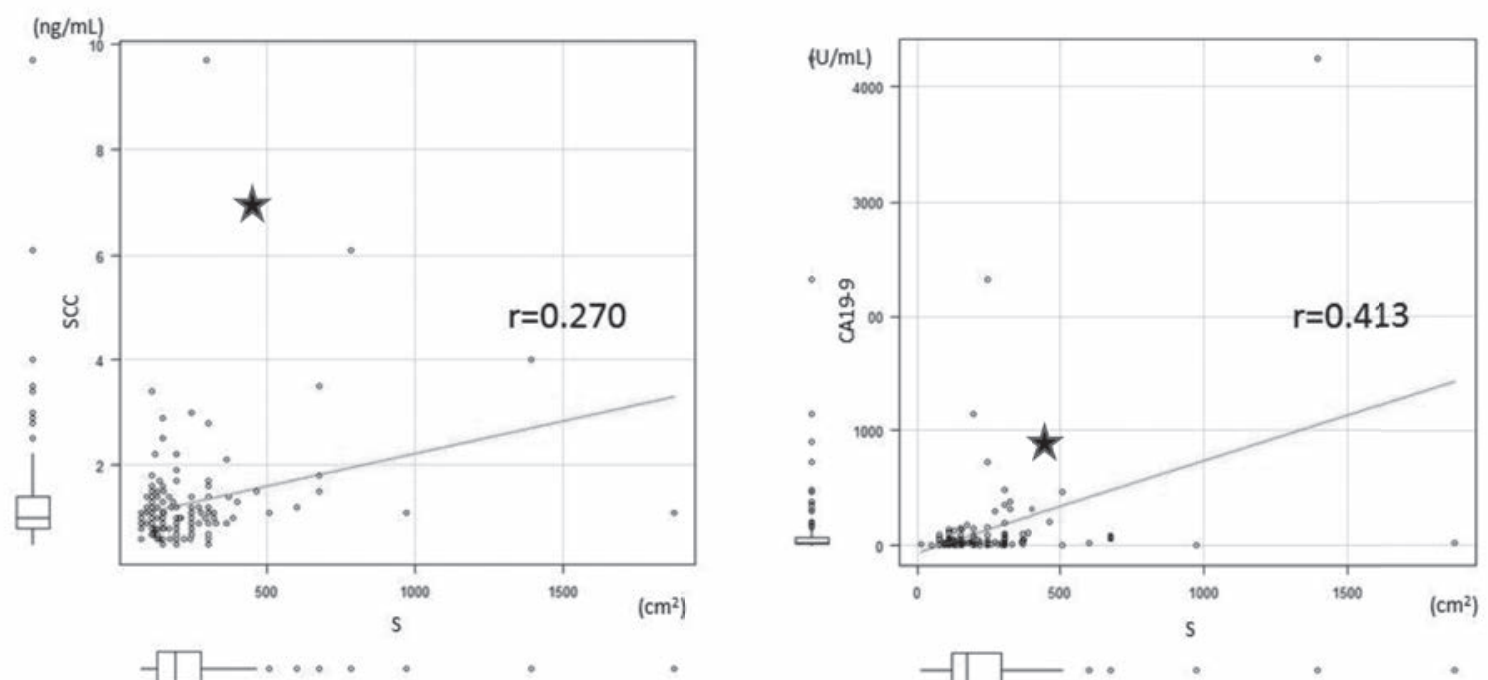

図 1 腫瘍マーカと腫瘍表面積の相関 : SCCとは弱い相関、CA19-9とは中等度の相関が認められた $(S$ : 腫瘍表面積 $r$ ：相関係数） $\star$ 印は悪性転化症例

表 2 術式の内訳

\begin{tabular}{lcc}
\hline & 腹腔鏡 $(\mathrm{n}=145)$ & 開腹 $(\mathrm{n}=40)$ \\
\hline 付属器摘出* & 45 & 24 \\
震腫摘出 & 100 & 16 \\
\hline
\end{tabular}

*対側囊腫摘出症例も含む

A

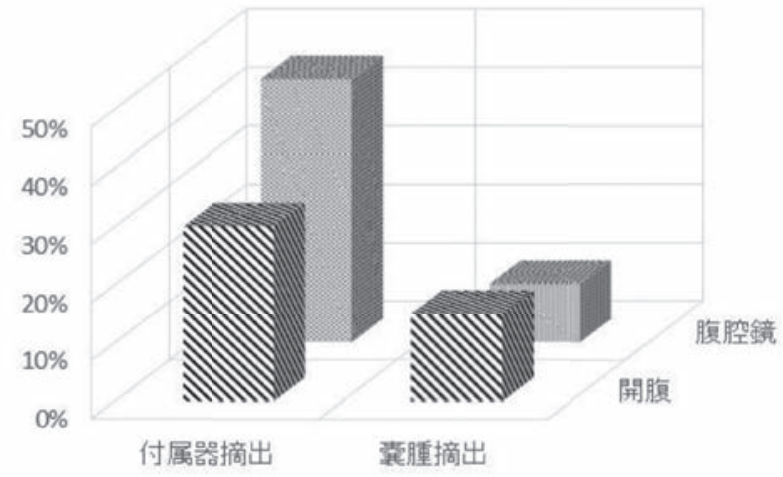

B

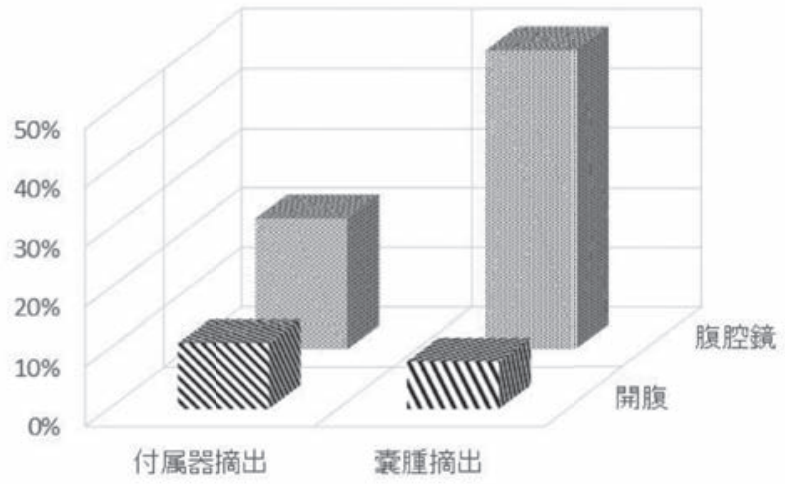

図2 茎捻転症例（A）と待機的手術症例（B）の術式分布 
表 3 術式間の臨床的特徵の違い

1. 開腹手術と腹腔鏡手術

\begin{tabular}{lccl}
\hline & 開腹 & 腹腔鏡 & $\mathrm{p}$ 值 \\
\hline 年齢 $\quad$ (歳) & $41.4 \pm 16.3$ & $33.6 \pm 9.6$ & $0.001>$ \\
腫瘍表面積 $\left(\mathrm{c} \mathrm{m}^{2}\right)$ & $289.5 \pm 355.5$ & $188.4 \pm 113.9$ & 0.006 \\
$\mathrm{SCC}(\mathrm{ng} / \mathrm{d} 1)$ & $1.97 \pm 2.27$ & $1.14 \pm 0.51$ & 0.0011 \\
$\mathrm{CA} 19-9(\mathrm{U} / \mathrm{ml})$ & $55.2 \pm 39.2$ & $72.7 \pm 149.5$ & 0.623
\end{tabular}

2. 付属器摘出術の有無

\begin{tabular}{lccl}
\hline & 付属器切除あり & 付属器切除なし & $\mathrm{p}$ 值 \\
\hline 年齢 (歳) & $46.3 \pm 12.4$ & $29.7 \pm 5.8$ & $0.001>$ \\
腫瘍表面積 $\left(\mathrm{c} \mathrm{m}^{2}\right)$ & $240.8 \pm 268.9$ & $191.1 \pm 129.7$ & 0.111 \\
$\mathrm{SCC}(\mathrm{ng} / \mathrm{dl})$ & $1.16 \pm 0.58$ & $1.32 \pm 1.19$ & 0.422 \\
$\mathrm{CA19-9}(\mathrm{U} / \mathrm{ml})$ & $94.0 \pm 189.3$ & $58.2 \pm 105.3$ & 0.163
\end{tabular}

器摘出を実施した症例としなかった症例において は年齢の平均值が付属器摘出実施群に扔いて有意 に高かった。

また、185例のうち術後 4 ケ月以上経過観察が されていた85例（両側付属器摘出症例を除く）に ついて再発の検討を行った。その結果、観察期間 の中央値は14ヶ月（4-84ケ月）であり、再発は 2 例（2.3\%）に認められた。

\section{考 察}

卵巣の成熟奇形腫は全卵巣腫演の $10-40 \%$ 占 めると言われている良性卵巣腫崵であり、日常臨 床に打いても頻繁に経験する われる症例に対する手術療法は若年者が多いこと から腹腔鏡手術を念頭に置いて術式を検討するこ とが多いが、他の卵巣腫瘍同様に悪性腫場である 可能性について検討した上で術式を決定する必要 がある。悪性腫韵の可能性を検討するための術前 検查として、MRIによる画像検查の他に腫瘍マー カー検查が一般的に施行されるが、今回の検討で も明らかなように成熟奇形腫が画像診断にて疑わ れる症例に损いては、CA19-9やSCCといった腫 瘍マーカーがしばしば異常值を示すため、術式の 判断を迷う症例が少なからず存在すると考えられ る。特にSCCが高い例においては悪性転化を念頭 に置く必要があるが、一般的には成熟奇形腫の悪 性転化は閉経後の症例に多く成熟奇形腫全体の $1-2 \%$ と少なくSCCの異常たけけで開腹や付属器摘 出といった侵襲的で卵巣予備能を下げる治療選択 を行った場合、過利治療例が増えることが懸念さ れる。Kikkawaらは37例の卵巣成熟奇形腫に発生 した扁平上皮癌 37 例の解析より、45歳以上で 10 $\mathrm{cm}$ を超える奇形腫を疑う腫韵ではSCCを測定す べきであるとしている3）。我々が経験した悪性転 化例は大きさについては $10 \mathrm{~cm}$ 超えていたが年 齢は30歳と若年であり成熟奇形腫の悪性転化とし ては典型的とは言えなかった。

今回の研究に捄いて患者背景は、腫瘍マーカー についてはCA19-9が41.0\%、SCCが17.2\%の割合 で異常值を示しており他の報告と同様の結果であ った ${ }^{46)}$ 。气の他の背景（年齢、側性、腫崵最大径、 茎捻転の頻度）についても諸家の報告とほほ同様 であったため、対象となった集団に関する選択バ イアスは少ないと考えられた年10)。腫瘍の大きさ とこれらの腫掦マーカー値との間にある程度の正 の相関が認められたことからCA19-9やSCCの異 常が認められた場合でも、腫犜の大きさが異常値 の原因である可能性も考慮し、日常臨床で行われ ているように画像検查所見などを併せた総合的な 判断で手術方法を選択する必要があると考元られ た。CA19-9 と成熟奇形腫の大きさとの関連性に ついてはいくつかの報告があり、関連性が見いだ せなかったとする報告もあるが5)、概ね大きいほ どCA19-9值が高くなる傾向であるとする報告が 多い 4 1.1-12)。CA19-9は血液型関連糖鎖抗原である Lewis A抗原 $\left(\mathrm{Le}^{\mathrm{a}}\right)$ がシアル化された A抗原であり、伊藤は成熟奇形腫における気管支 腺組織拉よび気管支上皮に拄けるCA19-9の局在 を示し、これらの組織から直接血流中に分泌され る以外に霉胞内に貯留し囊胞内で周囲毛細血管へ 漏出し血中へ移行するルートがあることを考察し た。またCA19-9の局在が認められなかった気管 支上皮組織においてはLeaが陰性であることを示 し、10\%程度存在すると考えられる遺伝的に $\mathrm{Le}^{\mathrm{a}}$ 
陰性症例においては成熟奇形腫症例でもCA19-9 は産生されないであろうと考察した ${ }^{13)}$ 。図 1 にお いて腫瘍表面積が著しく大きいにも関わらず CA19-9が正常值を示した症例はこのような背景 があるのかもしれない。一方でSCCと成熟奇形腫 の関係についての報告は少なく、Kataokaらの腫 瘍の長径とSCCとの関連性は認められないとする 報告やMoriらの健常群よりも成熟奇形腫群の方 がSCCの平均值が有意に高いとする報告があるが 今回の結果と単純に比較することは難しいと考え られた ${ }^{10,14)}$ 。

当院においては、術式は主治医の総合的な判断 と患者の同意により決定されており、術式選択に 共通したアルゴリズムは存在しない。しかしなが ら成熟奇形腫に対する待機的手術症例において は、開腹手術と腹腔鏡手術の比較では年齢、腫瘍 表面積、およびSCCの平均值は開腹手術において 有意に高く、また付属器摘出については付属器摘 出を含む術式を選択した群において年齢の平均值 が有意に高かったことからこれらの要因は共通し た判断材料となっている可能性が示唆された。茎 捻転症例については、腹腔鏡下付属器摘出術の割 合が多く、術中所見で血流不全により付属器摘出 が妥当であると判断された例が多かったと考えら れた。

再発に関して再発率は $2.3 \%$ と他の報告と同様で あったが ${ }^{15)}$ 、観察期間のばらつきが大きかったこ とや再発症例が2例のみであったため、更に症例 数を重ねて検討することが必要であると考えられ た。

(本論文の要旨は第54回日本産科婦人科内視鏡 学会において発表した）

\section{【文献】}

1) MATZ MH.: Benign cystic teratomas of the ovary. A review. Obstet Gynecol Surv 1961;16:591-605.

2) Ayhan A. et al: Mature Cystic Teratomas Of The Ovary: case series from one institution over 34 years. Eur J Obs Gynecol Reprod Biol 2000; 88(2): 153-7.

3) Kikkawa F. et al.: Diagnosis of squamous cell carcinoma arising from mature cystic teratoma of the ovary. Cancer 1998; 82(11): 2249-55.

4) Emin U. et al.: Tumor markers in mature cystic teratomas of the ovary. Arch Gynecol Obstet 2009; 279(2): 145-7.

5 ) Frimer M. et al:: Role of elevated cancer antigen 19-9 in women with mature cystic teratoma. Reprod
Sci 2014; 21(10): 1307-11.

6 ) 牧原夏子 他：卵巣奇形腫における悪性転化の術前 予測についての検討. 日産婦内視鏡学会 2014; 30(1): $112-6$.

7 ) Comerci JT. et al.: Mature cystic teratoma: a clinicopathologic evaluation of 517 cases and review of the literature. Obstetrics and gynecology 1994; 84: $22-28$.

8 ）金城盛吉, 千葉 裕, 田村是六. 最近 10 年間の当科に おける良性卵巣腫瘍の臨床統計. 産科と婦人科 1994; 61(6): 833-8.

9 ) 井浦俊彦 他：卵巣腫瘍茎捻転の疫学的考察. 産婦人 科の実際 1996; 45(9): 1247-51.

10) Kataoka T, Watanabe Y, Hoshiai H.: Retrospective evaluation of tumor markers in ovarian mature cystic teratoma and ovarian endometrioma. J Obstet Gynaecol Res 2012; 38(8): 1071-6.

11) Dede M. et al.: CA19-9 may have clinical significance in mature cystic teratomas of the ovary. Int $\mathrm{J}$ Gynecol Cancer 2006; 16(1): 189-93.

12) Cho H. et al.: CA19-9 elevation in ovarian mature cystic teratoma: discrimination from ovarian cancer -CA19-9 level in teratoma. Med Sci Monit 2013; 19: 230-5.

13）伊藤耕造：成熟䡬胞性奇形腫におけるCA19-9の意 義に関する研究. 日本産科婦人科学会雑誌 1992; 44: 524-528

14) Mori Y. et al.:Preoperative diagnosis of malignant transformation arising from mature cystic teratoma of the ovary. Gynecol Oncol 2003; 90(2): 338-41.

15）藤本麻葉 他：卵巣成熟囊胞性奇形腫の再発に関す る検討. 関東産婦誌 2012; 49: 679-82. 